\title{
Molecular Docking Study of Phenolic Compounds with Chitosan: Planning of Biodegradable Hydrogels with Antioxidant Action
}

\author{
Daniela Silva Sartori Delmondes ${ }^{a b}$, Pablo Henrique Delmondes ${ }^{a b}$
}

\begin{abstract}
${ }^{a}$ Grupo de Pesquisa em Ciências Estéticas e Cosméticas das Faculdades Unidas do Vale do Araguaia, UNIVAR, Barra do Garças, Mato Grosso, Brasil.
${ }^{b}$ Grupo de Pesquisa em Tecnologia Farmacêutica (TECFARM) das Faculdades Unidas do Vale do Araguaia, UNIVAR, Barra do Garças, Mato Grosso, Brasil.pablohdelmondes@hotmail.com
\end{abstract}

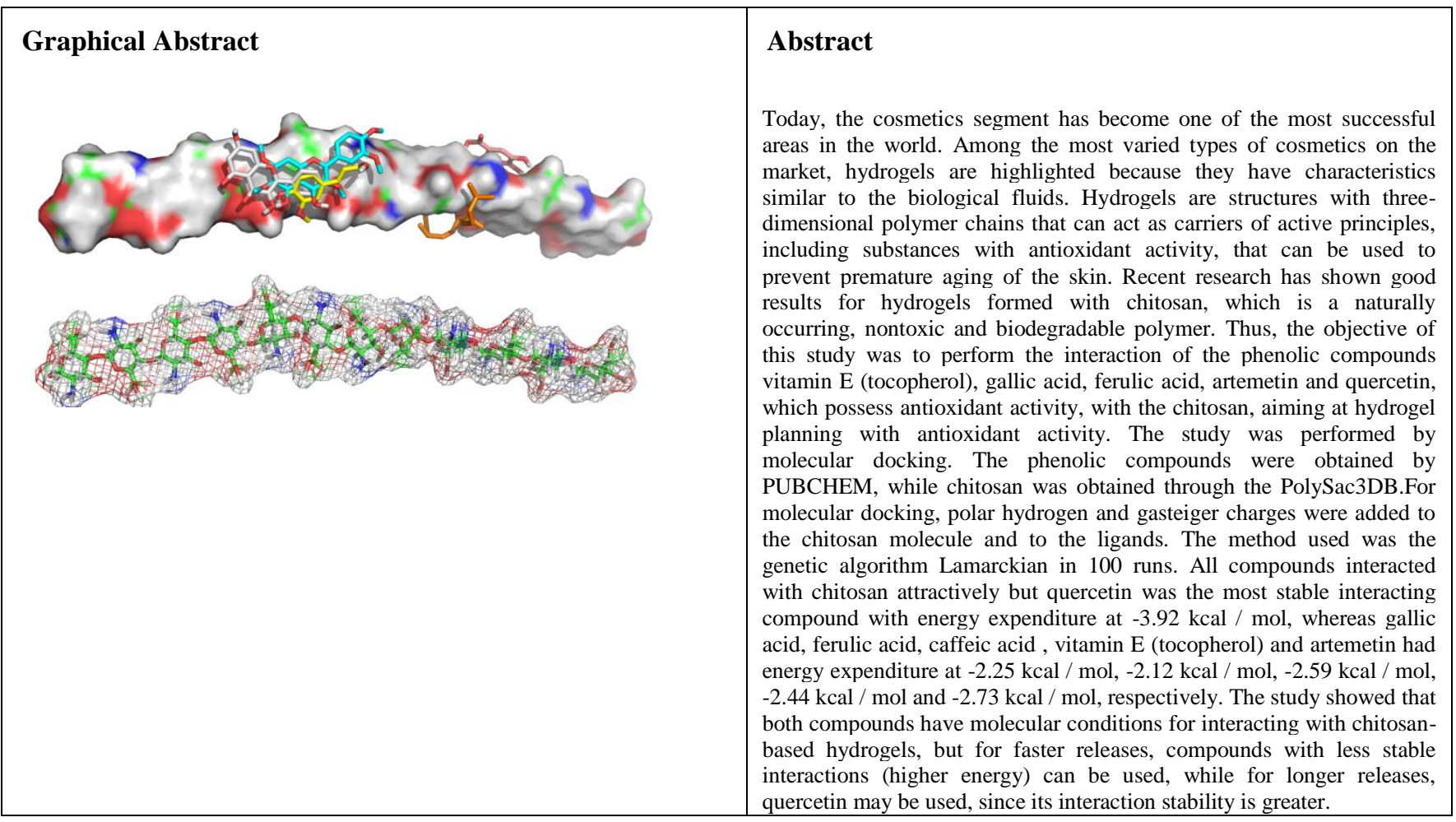

Keywords: antioxidant, hydrogel, biodegradable, molecular docking, chitosan.

\section{Introduction}

Currently, the cosmetics segment has established itself as one of the most successful areas in the world [1,2]. Among the most varied types of cosmetics on the market, hydrogels gain prominence, because they have characteristics similar to the biological fluids [3].

Hydrogels are structures with three-dimensional polymer chains that can act as carriers of active principles, including substances with antioxidant activity to be used in the prevention of early skin aging [3]. Recent research has shown good results for hydrogels formed with chitosan [4$6]$.

Chitosan is an extremely abundant naturally occurring polysaccharide. It can be found in smaller amounts in the cell walls and spores of some fungi, or can be obtained by the deacetylation of chitin, the main constituent of the arthropod exoskeletons. Chitosan is nontoxic, biodegradable, hypoallergenic, has an easy gel formation [7-9], and antimicrobial activity that, together with its low cost, makes it a major target for research and applications in agriculture, medicine, the environment, food and cosmetics [8].

Like chitosan, phenolic compounds, as they have antioxidant activity, besides others, they have been widely used in diverse research, mainly as additives incorporated in polymer bases. Several studies have presented the antioxidant action of phenolic compounds such as phenolic acids (gallic acids, ferulic acid, caffeic acid and others), flavonoids (quercetin, artemetin and others) and some vitamins (tocopherol and others) [10-12].

Molecular modeling, which is defined as the investigation of structural, chemical and physicochemical aspects through computational chemistry and graphical 
visualizations, it has been widely used in the research of new active substances, interaction between drugs and macromolecules and in the development of new materials $[13,14]$.

Due to the low cost and the research time, it is necessary to use molecular modeling in the interaction of active compounds with polymer bases to predict the most promising compounds.

Based on this perspective, the objective of this work was to conduct a molecular docking study between the phenolic compounds gallic acid, ferulic acid, caffeic acid, tocopherol, quercetin and artemetin against chitosan, aiming at a molecular approach and the choice of the best antioxidant additive for future synthesis of antioxidant hydrogels.

\section{Materials and Methods}

For the molecular docking studies, a 12-mers chitosan molecule was obtained in PDB (Figure 1), through the PolySac3DB polysaccharide bank $[15,16]$. The chitosan structure was optimized by the AMBER force field [17], present in the Gabedit software [18].

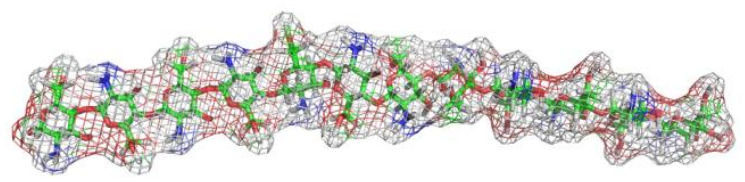

Figure 1. 12-mers chitosan optimized by the AMBER force field.

The structures of the phenolic compounds were obtained through PUBCHEM [19], which is an international molecule bank. After obtaining the phenolic compounds, they were optimized by the semi-empirical method MP7, through the software MOPAC [20].

In the Autodock 4.2 software [21], which was used for the study of molecular docking, gasteinger charges and polar hydrogens were added in the chitosan molecule, which then, like the phenolic compounds, was saved in the pdbqt extension.
Autogrid 4.2 was used to generate a three-dimensional grid around the entire chitosan molecule. The grid around the chitosan had dimensions in $52 \AA$ on the $X$-axis, $126 \AA$ on the $\mathrm{Y}$-axis and $40 \AA$ on the $\mathrm{Z}$ axis, $0.606 \AA$ spacing (Figure 2).

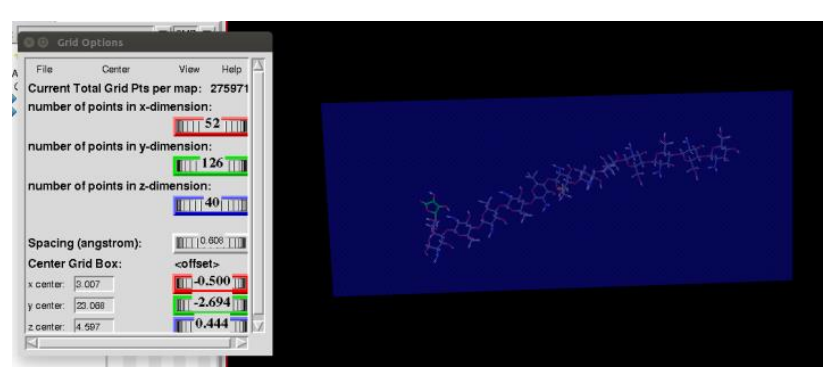

Figure 2. Grid formed around the chitosan molecule

To find the most stable conformations of the ligands, we used the Lamarckian genetic algorithm (LGA). The initial population was defined as 150 and the search process occurred through random initial conformations. The maximum value of energy assessments chosen was $25,000,000$, while the maximum number of generations was maintained at 27,000 , just as the number of elitism was kept at 1 . The genetic mutation and crossover rates were respectively 0.02 and 0.80 . After completing the calculations, 100 different conformations were obtained and grouped into different clusters, defined by energy proximity and RMS (Root Mean Square deviation) values, according to the AutoDock default. During the search process, chitosan was kept rigid and the binders flexible.

\section{Results and Discussion}

All phenolic compounds involved in the study interacted attractively with the chitosan molecule. However, quercetin, with an energy expenditure of -3.92 $\mathrm{kcal} / \mathrm{mol}$ (Table 1), was the compound that obtained the lowest energy expenditure, which interacted more stable with the polymer. Figure 3 shows the complexes formed between chitosan and phenolic compounds.

Table 1. Results of the molecular docking study between phenolic compounds and chitosan

\begin{tabular}{ccccc}
\hline Complexo & $\begin{array}{c}\text { Binding } \\
\text { energy } \\
\text { (kcal/mol) }\end{array}$ & $\begin{array}{c}\text { Vdw + hb } \\
\text { + desolv } \\
\text { energy }\end{array}$ & $\begin{array}{c}\text { Eletrostatic } \\
\text { energy }\end{array}$ & $\begin{array}{c}\text { Torsional } \\
\text { energy }\end{array}$ \\
\hline $\begin{array}{c}\text { Gallic acid } \\
+ \text { chitosan }\end{array}$ & -2.25 & -3.35 & -0.39 & 1.49 \\
$\begin{array}{c}\text { Ferulic } \\
\text { acid + } \\
\text { chitosan }\end{array}$ & -2.12 & -3.08 & -0.53 & 1.49 \\
$\begin{array}{c}\text { Artemetin } \\
+ \text { chitosan } \\
\text { Quercetin } \\
+ \text { chitosan } \\
\text { Caffeic }\end{array}$ & -2.73 & -4.85 & -0.02 & 2.09 \\
$\begin{array}{c}\text { acid + } \\
\text { chitosan }\end{array}$ & -2.59 & -5.49 & -0.21 & 1.79 \\
$\begin{array}{c}\text { Tocopherol } \\
+ \text { chitosan }\end{array}$ & -2.44 & -3.53 & -0.5 & 1.49 \\
\hline
\end{tabular}


a)
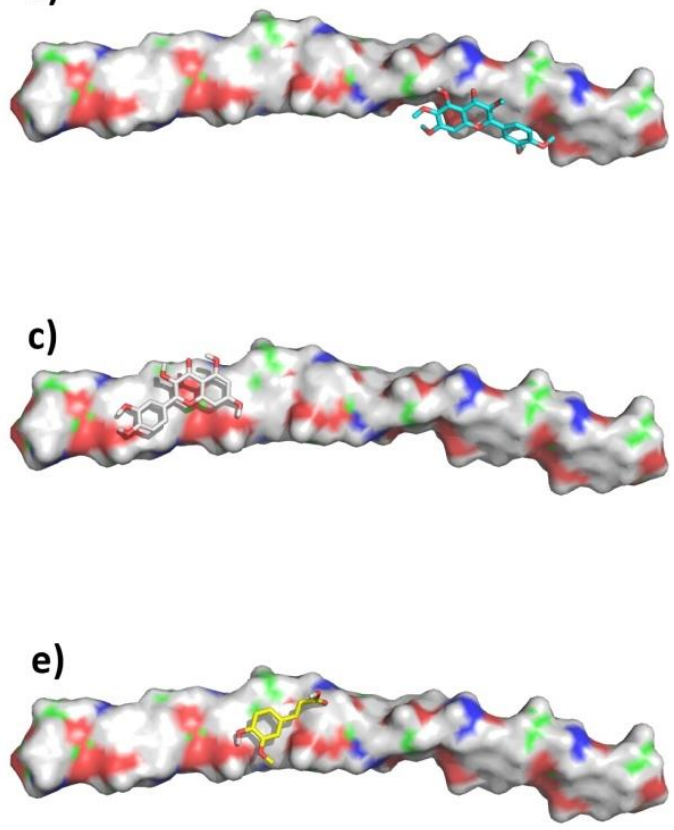

b)

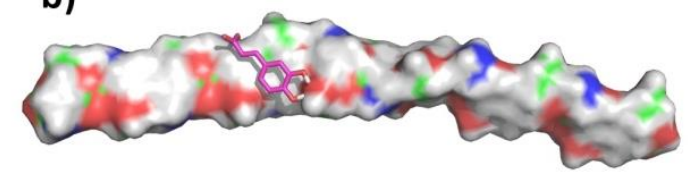

d)

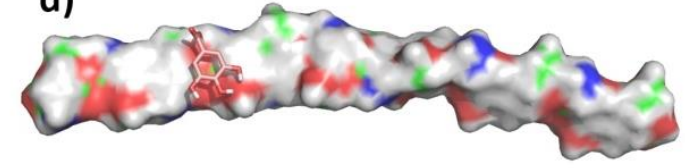

f)

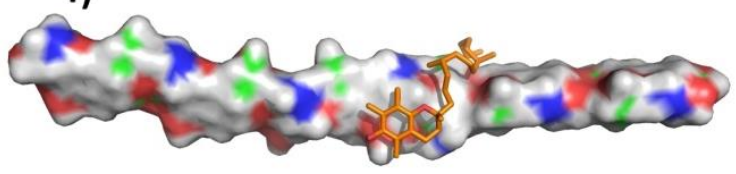

Figure 3. Interactions of phenolic compounds with chitosan. a) artemetin; b) caffeic acid; c) quercetin; d) gallic acid; e) ferulic acid; f) tocopherol.

It is observed in Figure 3 that the compounds gallic acid, artemetin, ferulic acid and caffeic acid, occupy the same site of interaction in the most stable conformation.

In the docking study it was also observed that the interactions of van der waals and hydrogen bonds were predominant in the interactions between the compounds with the chitosan.

\section{Conclusions}

The study shows that all compounds involved in the study are good candidates for interacting with chitosan. As hydrogels are polymeric bases which release active principles at the application site, there is the possibility of planning the hydrogel according to the release rate of the desired antioxidant. For slower releases, quercetin, which has a more stable interaction with chitosan, can be used, while for faster releases, another compound, the less stable interaction, may be used.

\section{Conflicts of Interest}

The authors declare no conflict of interest

\section{References}

[1] Bertolini, G. R. F., Rojo, C. A., \& Lezana, A. G. (2012). Modelo de análise de investimentos para fabricação de produtos ecologicamente corretos. Revista Gestão \& Produção, São Carlos, 19(3), 575-588.
[2] Morquio, A., Rivera-Megret, F., \& Dajas, F. (2005). Photoprotection by topical application of Achyrocline satureioides ('Marcela'). Phytotherapy Research, 19(6), 486-490.

[3] Balestrin, L. A. (2015). Desenvolvimento de hidrogéis contendo extrato de Achyrocline satureioides incorporado em nanoemulsões visando à atividade antioxidante.

[4] Brant, A. J. C. (2008). Preparação e caraterização de hidrogéis a partir de misturas de soluções de quitosana e poli (N-vinil-2-pirrolidona) (Doctoral dissertation, Universidade de São Paulo).

[5] Azevedo, E. P., \& Kumar, V. (2016). THE USE OF A NOVEL ALDEHYDE-FUNCTIONALIZED CHITOSAN HYDROGEL TO PREPARE POROUS TUBULAR SCAFFOLDS FOR VASCULAR TISSUE

ENGINEERING APPLICATIONS. Química Nova, 39(9), 1071-1077.

[6] Sanfelice, A. M., \& Torrado Truiti, M. D. C. (2010). Produtos em filme-Inovação na tecnologia de cosméticos. Acta Scientiarum. Health Sciences, 32(1).

[7] Aider, M. (2010). Chitosan application for active biobased films production and potential in the food industry. LWT-Food Science and Technology, 43(6), 837842.

[8] Goy, R. C., Morais, S. T., \& Assis, O. B. (2016).

Evaluation of the antimicrobial activity of chitosan and its quaternized derivative on E. coli and S. aureus 
growth. Revista Brasileira de Farmacognosia, 26(1), 122127.

[9] Canella, K. M. N. C, \& Garcia, R. B. (2001). Caracterização de quitosana por cromatografia de permeação em gel-influência do método de preparação e do solvente. Quim. Nova, 24(1), 13-17.

[10] Degaspari, C. H., \& Waszczynskyj, N. (2004). Propriedades antioxidantes de compostos fenólicos. Visão acadêmica, 5(1).

[11] Lordêlo Cardoso Silva, M., Silva Costa, R., dos Santos Santana, A., \& Bello Koblitz, M. G. (2010). Compostos fenólicos, carotenóides e atividade antioxidante em produtos vegetais. Semina: Ciências Agrárias, 31(3).

[12] Angelo, P. M., \& Jorge, N. (2007). Compostos fenólicos em alimentos-Uma breve revisão. Revista do Instituto Adolfo Lutz, 66(1), 1-9.

[13] Delmondes, P. H., \& Stefani, R. (2017, January). Computational Study of Natural Phenolic Acid Solubility and Their Interactions with Chitosan. In Proceedings of MOL2NET 2016, International Conference on Multidisciplinary Sciences, 2nd edition (p. 1). MDPI AG.

[14] Delmondes, P. H., \& Stefani, R. (2018). In silico Study of the Antichagasic Activity of Aromatic Compounds. Orbital: The Electronic Journal of Chemistry, 10(5).

[15] SARKAR, Anita; PÉREZ, Serge. PolySac3DB: an annotated data base of 3 dimensional structures of polysaccharides. BMC bioinformatics, v. 13, n. 1, p. 302, 2012.

[16] Sarkar, A., \& Pérez, S. (2013). PolySac3DB: an annotated data base of 3 dimensional structures of polysaccharides. Glycoconjugate Journal, 30(1), 1-1.

[17] Pearlman, D. A., Case, D. A., Caldwell, J. W., Ross, W. S., Cheatham III, T. E., DeBolt, S., ... \& Kollman, P. (1995). AMBER, a package of computer programs for applying molecular mechanics, normal mode analysis, molecular dynamics and free energy calculations to simulate the structural and energetic properties of molecules. Computer Physics Communications, 91(1-3), 141.

[18] Allouche, A. R. (2011). Gabedit - a graphical user interface for computational chemistry softwares. Journal of computational chemistry, 32(1), 174-182.

[19] Kim, S., Thiessen, P. A., Bolton, E. E., Chen, J., Fu, G., Gindulyte, A., ... \& Wang, J. (2015). PubChem substance and compound databases. Nucleic acids research, 44(D1), D1202-D1213.

[20] Stewart, J. J. (1990). MOPAC: a semiempirical molecular orbital program. Journal of computer-aided molecular design, 4(1), 1-103.

[21] Morris, G. M., Goodsell, D. S., Huey, R., \& Olson, A. J. (1996). Distributed automated docking of flexible ligands to proteins: parallel applications of AutoDock 2.4. Journal of computer-aided molecular design, 10(4), 293-304. 